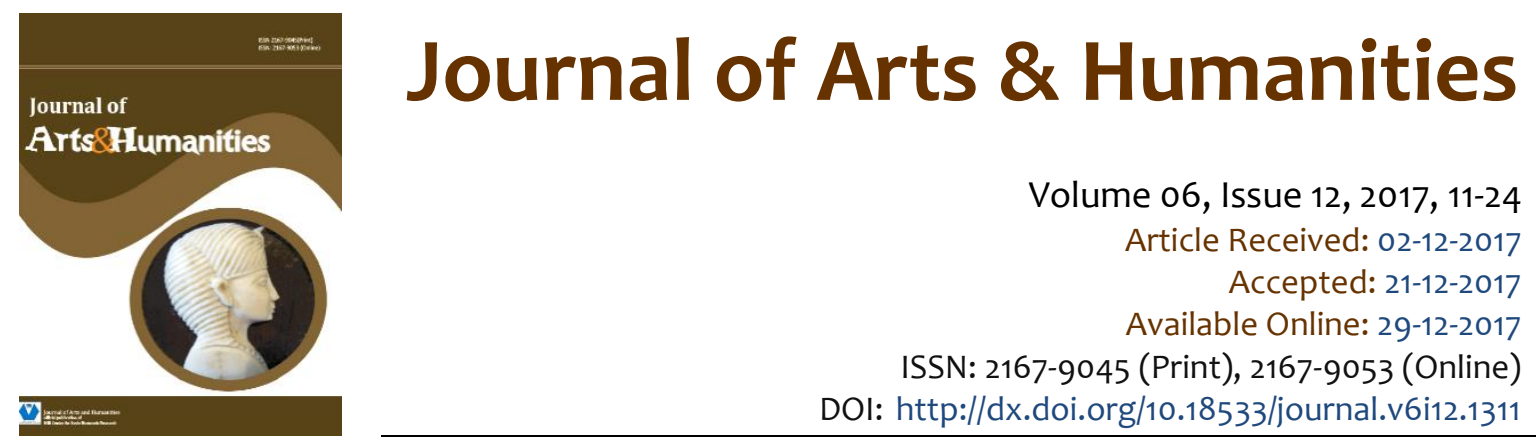

\title{
Rethinking Materiality in Pre-Tertiary Studio Art Education in Ghana
}

\author{
Kwame Opoku-Bonsu', Yaw M. Jectey-Nyarko², Felix A. Anim³, Emmanuel E. Donkor ${ }^{4}$
}

\begin{abstract}
This paper explores the conventional artist and environment connections, and argues that, environment that produce the Senior High School student do so with peculiar material affinities and competences ripe for 21st century art. The culture of obliging student to a few institutionalised media like clay, dyes and paints in the studio based art disciplines inhibit the numerous possibilities available, and confines art education to limited aptitudes and few institutionally expected expressions in pre-tertiary art education in Ghana. Authors believe this practice is inconsistent with global art education trends and well-being of the artist's person in the 21st century art practice. Using content analysis, the paper examines the Art Curricula and WAEC examination questions for Art Students, and institutional bureaucracies and antiquated curriculum philosophies were revealed as being responsible for the present state of affairs, and keep bedeviling the numerous curricula reviews. The paper therefore recommends curricula and examination item reviews, as well as the incorporation of visual and material culture into curricula philosophies to cure the prevailing phenomena. Authors also argue for policy on inclusive curricula, and are convinced that, incorporating these into artistic processes would democratize media choices, allow familial cultural frames, to usher in an art education premised on cultural production and meaning making, with diverse material and visual competences.
\end{abstract}

Keywords: Competence, Materiality, Media, Visual Art Examination Questions, Visual Art Syllabi.

This is an open access article under Creative Commons Attribution 4.0 License.

\section{Introduction}

Ghana's pre-tertiary art education is expected to train students to participate in on-going cultural conversations (Heijnen 2015, p.289), but the visual art curriculum for the Senior High School

\footnotetext{
${ }^{1}$ Department of Painting and Sculpture, Faculty of Art, College of Art and Built Environment, Kwame Nkrumah University of Science and Technology, Kumasi - Ghana. E-mail: kopoku-bonsu.art@knust.edu.gh

2 Department of Painting and Sculpture, Faculty of Art, College of Art and Built Environment, Kwame Nkrumah University of Science and Technology, Kumasi - Ghana. E-mail: ymjectey-nyarko.cass@knust.edu.gh

3 Department of Painting and Sculpture, Faculty of Art, College of Art and Built Environment, Kwame Nkrumah University of Science and Technology, Kumasi - Chana. E-mail: faanim.art@knust.edu.gh

4 Department of Painting and Sculpture, Faculty of Art, College of Art and Built Environment, Kwame Nkrumah University of Science and Technology, Kumasi - Ghana. E-mail: eyramkdonkor@yahoo.com
} 
(SHS) in Ghana is fraught with numerous inconsistencies amidst teacher apathy and students disenchantment (Essel et al 2014; Flolu 1997; Opoku-Asare \& Siaw 2016; Opoku-Asare, Tachie-Menson \& Essel 2015; Opoku-Asare, Tachie-Menson \& Ampeh, 2015). There are other curricula infractions that have to do with curricular cultural requirements and its contemporaneous tuning as inhibitions to art development, and artists as cultural practitioners (Edusei 2004; kari kacha seidou 2014a; 2014b). Colonial art education policies have produced apparent curricula trait of standardization with institutional memory of materials and competence that has survived Ghana's independence, and numerous curricula reviews (Boasiako \& Asare 2015; CRDD 2010; seidou 2014a; 2014b; Woets 2012). Its standardization has to do with its universal application, and material prescription, skill and meaning restrictions irrespective of one's geographical or biopsychosocial dispensation (Essel et al 2014; OpokuAsare \& Siaw 2016). Such curriculum has the tendency of burdening student with its requirements regardless of their states (Edusei 2004; Heijnen 2015; kari kacha seindou 2014a; 2014b). The curriculum is traditional, pigeon-holed into traditional basketry, ceramics, graphic design, jewellery, painting, sculpture and textiles, topped with general knowledge in art (GKA), and defy overlapping even when it is suggested.

With the foregoing in the $2^{\text {nd }}$ decade of $21^{\text {st }}$ century, one is tempted to raise series of critical questions bothering on prevailing practices and objects. Do weaving and sewing always have to be categorised as basketry, textile and fashion? How do we categorise doll making and rattan mannequins for wigs and clothes? What do these represent in our consciousness and social environment? Do their materiality identify with definitions in current art trends elsewhere? Answers to these questions would form the bases for the assessment of present material content at the SHS and West African Examination Council's (WAEC) West African Secondary Schools Certificate Examinations (WASSCE), to determine whether or not the curricula and examination questions need modifications. It will also help to determine whether there is the need for competence re-evaluation to "deskill and reskill" our aptitude contents of the art syllabi (Roberts 2010; 2007). The nature of skill endorsed by the SHS syllabi (CRDD 2010), as argued by kari kacha seirdou (2014a; 2014b), is inadequate for art practice of today. It favours traditional craft-base object production, but artistic skill ... "is the cross-disciplinary outcome of an ensemble of technical and intellectual skills" (Roberts 2010, p91), "away from the execution of forms of expressive mimeticism" (Roberts 2011, p43). It is with these backgrounds that "rethinking and reinscribing" materiality and competence in the syllabi is construed. Deskilling and reskilling in art is modern, and ongoing dialectically, negotiating socially relevant skills, whether scientific, technological or prosthetic. In the light of this, the $21^{\text {st }}$ century art training should aim at the "world of signifiers and materials that require forms of mapping, superimposition and coordination" (Roberts 2010, p83).

Ghana like most African countries do not prioritize art as a significant cultural production worthy of serious attention and resources (Artwatch Ghana 2017; Efland 2007; Heijnen 2015). In policy, art is reduced to needed hands in the informal sector of the economy, tourism and preservation of indigenous heritages in the arts (Annku \& Flolu 2012; GoG 2004). Even though creative arts is part of the pre-tertiary formal education system, national apathy leaves much to be desired. Hence content of art education has not been reflective of Ghanaian cultural environment (Edusei 2004; Masoga 2005). Owing to the above, visual art education in Ghana is fraught with inefficiencies and misconceptions that have to do with teacher and student apathy and tutorial relationships, interests and performances rates in their relationships with curricula and teaching methods (Flolu 1997; Opoku-Asare \& Siaw 2016; Opoku-Asare, Tachie-Menson \& Essel 2015; Opoku-Asare, Tachie-Menson \& Ampeh, 2015). For instance, Opoku-Asare, Tachie-Menson \& Essel (2015) see admission inequalities and their influence on tutorial culture and perception of students as contributing factors. Others like Edusei (2004) and kari kacha seindou (2014a; 2014b) have curricula and philosophical problems, based on relevance of prevailing art education and contemporary society. Edusei (2004) for instance, advocates for a bridge between curricula, teaching and indigenous arts of the beneficiary society towards building cultural content, whiles seirdou traced the apparent curricula failure to persistent colonial educational policies.

The paper looks at the standardization of the Ministry of Education (MoE) / Ghana Education Service (GES) Art Syllabi (curriculum) for the Senior High Schools in Ghana (CRDD 2010) with its traditional categories and their material preferences, and how these engender student interests and $21^{\text {st }}$ century art practice. Authors therefore compared the SHS Art Syllabi with the WAEC's WASSCE questions to reveal apparent collaborations that inform standardization of successive curricula and 
their materiality, implicating WAEC examinations, GES institutional memories and lack of policy framework in the current visual art curricula performance.

The logic of visual in art is premised on materiality (Du Preez 2008; Grosz 2008; Hansen 2007; Rose 2002; Mills 2009; Mirzoeff 2011; 2006; 1998). This is a combination of material and immaterial natures of materials (Mills 2009). Materials, by associations and experiences, organise themselves into immediate, accepted and probable. The choices, within probability, present and acceptability in media modes conform to a range of artistic competences and interpretations. Probable, acceptable and present materials work in various complex ways to articulate and circulate meanings culturally. Our experiences with specific environment determine how materials available, become feasible, subsequently accepted through use (Derrida 1997). These form our experiences of materials (Grosz 2008), and their complex relationships with people with needs become contexts for creation, artistic or otherwise. Artistic media and contexts therefore become philosophy of the forms documented in history of art; i.e. history of philosophy of art (Carrol 2002, p3), as concepts that are key to practices and activities of art, past and projected.

Activities of art, for this paper have been broken into four overlapping areas. These are provenance, transmission, maintenance and economy of art. Provenance, on which this paper focuses, looks at activities that create art. These include art making processes, techniques, methodologies and institutions; materials, tools and artistic provisions; scholarships of art techniques and meaning making; actual and virtual presences and exhibitions. They impact maintenance and condition transmission and economy of art. Transmission in art is about art patronage and dissemination. Maintenance of art flourishes through generational bequests that are carried on by art education and institutions of art (teaching and learning/research). These are made up of indigenous structures, established customs and informal practices (apprenticeship and mentorships systems), as well as research institutions and foundations and formal art education in $21^{\text {st }}$ century. These are geared towards creating competent artists and creative people through cultural exchanges in the economy of art. The ever expanding economy of art takes into consideration cultural exchanges, subsistence, trade, institutional foundations, as well as the socio-cultural benefits engendered by and through art. Where provenance fails, transmission suffers and affects maintenance and economy of art.

In this regard, artistic concept, practice and activity found in the making of art complicate the mandate of transmitting materiality and thoughts, prevailing and precursors in every significant work of art. Material then becomes the vehicle through which art acquires its physical and mental presence (Du Preez 2008; Grosz 2008; Hansen 2007; Rose 2002; Miller 2011; Miller 2001b; Mills 2009; Mirzoeff 2011; 2006; 1998; Rose 2002). Through contact and associations as well as the memory created by the material's culture, a material articulates several meanings (Grosz 2008; Hansen 2007). It is crucial that, in training those tasked with future construction of meanings, the meaning making process of art would be critically examined early (Miller 2011).

\section{Institutional art materials}

Scholars widely agree on the meaning making capabilities of materials, especially those that are within one's environment (Buchli and Lucas 2001; Du Preez 2008; Harrison and Schofield 2009; Mills 2009; Miller 2001a; 2001b). Environment here is construed as socio-cultural and spatio-temporal complexities of a place, affecting entities that occupy it (Jones and Cloke 2008), and material as building blocks of art, used interchangeably with media where appropriate. This widely acclaimed philosophy is adequately confirmed in histories of art and material cultures across time (Buskirk 2003; Carrol 2002; Cottington 2005; Grosz 2008; Smith 2011). Ghana's formal art education at the SHS, regards this material/meaning complexity differently for various reasons (sei ${ }^{n}$ dou 2014a; 2014b; sei ${ }^{n}$ dou et al 2015). Material content at this level of pre-tertiary studio art education is characterised by the preference for conventional media like clay, wood, paper, pigments (including dyes), yarns and palm branches (CRDD 2010). The concept of pure culture in this paper is a hybridised formulation, from material cultures in microbiology and archaeology, as original, or primary material, to contrast contemporary material culture as processed or post-industrial objects in Daniel Miller sense (Miller 2011, p1). These materials have their institutional recognitions to curricula inscriptions by second cycle institutions, especially those under GES. These materials, though good in various ways, are to a large extent, bland and transitory, and incapable of meaning in themselves compared to the multitudes of 
vernacular options outside the institutional choices (Heijnen 2015). The SHS syllabi in Ghana (CRDD 2010) do not only reveal material preferences, but directions and techniques, which oblige teachers and students to specific materials and methodologies. The authors' delimitation of the SHS level stems from its complex position in the development of the individual, at the intersection of adolescence and adulthood; amateur and professional.

seindou (2014a) argues that, art education in Ghana has certain colonial vestiges that are antithetical to art. This is because foundations upon which art education in Ghana is built was for the training of skilled manpower in a faux colonial industries; an industrial agenda for colonial commonwealth, to train technical and manual labour with a set of curricula adaptations. This form of training tends to favour pure cultures like clay and pigments, because of their implications on industrial design and productions (p11). Administering of art programmes at SHS level, and the preferences of these materials are as a result of conditions prevailing in institutions of higher learning in art in Ghana. They include, the histories of educational system (sei ${ }^{i}$ dou 2014a; 2014b), knowledge base of tutors at the SHS, (Flolu 1997; seindou 2014a; 2014b), course structures and syllabi (Boasiako and Asare 2015; CRDD 2010; Tonah 2009) and end of study examination requirements by the WAEC. WAEC, through questions for SHS Candidates in its WASSCE articulate form and content, and solicit programmed material competences and methodologies. These inform mock question models and corresponding capacities, and institutional programming. These observations question "ethics of foundation" of our art institutions (Madoff 2009, pp ix), and how these foundations incorporate the new in curricula formulation (Andrus 2012; Gude 2004; NAEA 2010; Pujol 2009).

Studies by kari kacha sei^dou (2014a; 2014b) suggest that, Ghanaian art curricula, irrespective of the numerous revisions (Boasiako and Asare 2015; MoE 2010; CRDD 2010) retain these industrial requirements against proper development of art. Art is personal, and any training worthy recognise this, and allow for the development of the artist person (Gude 2004). seindou shares this with different observations in art education elsewhere (see NAEA 2010; Heijnen 2015; Madoff 2009; Pujol 2009), and has restated these on numerous formal and informal platforms that, these residues elude syllabi designers (Woets 2012; seir dou et all 2015), ignore the needs of $21^{\text {st }}$ Century student, and the knowledge base of SHS teachers who are products of the education system.

Different people approach materials differently, and circumstances surrounding persons' relationships with particular materials/objects are based on other meanings generated through their associations with places, people and other objects (Andrus 2012; Du Preez 2008; Buchli \& Lucas 2001). We believe that the cure to present observations lies in the integration of local meaningful pure cultures, and more importantly, material and visual cultures available geographically to candidates and their associated aptitudes into the art curricula. Here, Emiel Heijnen's Remixing the Art Curriculum: How Contemporary Visual Practices Inspire Authentic Art Education (2015): Olivia Gude's Postmodern Principles: In Search of a 21st Century Art Education (2004) and Considerations for a 21st-Century Art \& Culture Curriculum (2007), Kerry Freedman's Teaching Visual Culture: Curriculum, Aesthetics, and the Social Life of Art (2003), and, Lynn Erickson's Concept-Based Curriculum and Instruction: Teaching beyond the Facts (2005) are of great resources for creating credible 21st-Century Art curricula. This, when done, would result in multiple media use, taking into consideration candidates' backgrounds, vernacular competences and candidates' familiarity into the studio art curricula (Freedman 2003; Erickson 2005). Candidates' determined materials would create platforms for the discussions of value and legitimacy of their work, and would be a boost for candidates' material/ environment/ memory interpretations (Heijnen 2015; Heidegger 2001) that can be carried into their art (Krauss 1999, as cited in Du Preez 2008). This will also create environments for integration of popular, material and visual cultures by negotiating traditional competences in material manipulations, socio-cultural aptitudes and conceptual thinking (Freedman 2003; Erickson 2005; Gude 2007; 2004; Roberts 2011; 2010).

Material considerations for art at the SHS level and the WASSCE examinations do not reflect above issues (CRDD 2010). Apart from the materials and methods mentioned in the syllabi of the SHS, others are not captured or accepted. While some materials and techniques in different categories make them impossible in others, e.g. Sculpture/basketry/jewellery, painting/graphic design, others can only be approached as transitory, e.g. computer generated designs, and mould making materials, cannot be explored as ends in themselves. For instance, candidates who weave mat, smock or basket, by 
experience, cannot approach them sculpturally, away from the syllabi's categories of basketry and textiles respectively.

Another difficulty is the institutional framework for teaching and learning of art which has been modelled on the text-based courses at the SHS level and other cultural baggage (Stankiewicz 2009;

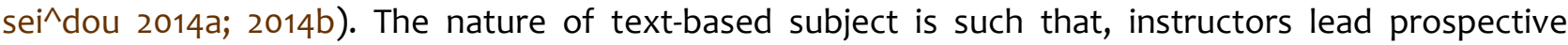
agenda by transference, and students by inference. Although there are text-based courses within art education, their form and requirements differ from the studio based ones, which are situated within memory, reflection and projection. Traditionally, a student of art at the SHS level comes into the studio space expecting teachers to lead through curricula instructions even for independent projects. Curricular framework is oblivious of the fact that accepted materials have their residual effects in aptitudes and excellence, and can similarly be approached from different materials and objects. This together with efficient history of art regimes are possible cures, and arguably beneficial to candidates creating specific meanings, through their own materials, within institutional frameworks, and along with the curricula media.

\section{Senior high school art syllabus}

The ensuing paragraphs shall examine the present SHS Art curricula in Ghana through the sculpture syllabus (authors' area of specialty and could speak to issues and materiality thereof). The Ministry of Education SHS Visual Art Syllabi (MoE/CRDD 2010) is well intended as vocations with specialized fields in art, in response to overarching craft industry and tertiary educational structure into which its products would enter. The syllabi covers a 3-year SHS Visual Art programme administered through the numerous Senior High Schools (SHSs) which specialize in part or the entire curricula. It has the mission to provide institutional framework for the standardize teaching and learning of art at the SHS level, with objectives to train creative people for art and related industries in Ghana; train artisans who are capable of practicing on exiting SHS; and, above all, groom candidates for higher education in art in Ghana upon certification.

As vocations, the 3-year programme incorporate entrepreneurial studies for artisanal and small scale industry. It features some exhibition protocols, and breaks individual goals and subjects into units e.g. developing a Business Plan (SHS1: Section 4 Units 2). Programmes like Art as Vocation; Materials, Tools and Equipment; Design and Art Making; Exhibition and Entrepreneurship are sections with units in Years 1, 2, and 3, depending on the levels intended (CRDD 2010, p iv). Each curriculum is broken into average of 9 sections and 5 units as instructions, with expectations of producing experts capable of functioning prior to, or independent of tertiary education. It is therefore expected, that, an SHS graduate would have competences in sculpture craft, explore materials and tools, knowledges in histories, studio practices and safety, tools and materials, exhibitions and commissions, siting and managing of craft industry.

SHS graduates are expected to know, for instance, carving, modelling, casting (all forms), lettering, assemblage and construction, not in texts, but by hands-on practice. They are to have knowledge in materials, tools handling and studio maintenance, establishment and management of small scale industry, costing and pricing, exhibition, and building of portfolios, mounting of exhibitions, managing of art enterprise and appreciation and criticism. All of these are subjects and units that expand them in detail. For instance, professional practice has developing of business plan, business brochure, call cards, and artist's statement among other things as units to build graduate professionals.

A study of the syllabi (MoE/CRDD 2010) for art at the SHS level reveals structural overloads for the 3 year programme. These overloads limit space availability for experimentations that would help candidates understand their undertakings. Separating casting and carving into traditional/indigenous amount to duplications, and having lettering outside design just populate curricular space and congest timetables, like many others (piv).

Secondly, basic entrepreneurial skills, which includes portfolio building; artist's statement and business plan; business brochure and card, could easily belong to different spaces and units. For instance, building portfolio and artist statement (CRDD 2010, SHS1: S4 Units1\&3) could be incorporated into exhibition. In the same vein developing a business plan and business brochure and card (SHS1: S4 Units2\&4) could be moved into entrepreneurship (SHS3:S2) for obvious reasons to relieve the syllabi of 
congestions, create space for art history and exegeses (on materiality), and to include experimentation from personal experiences, which could inaugurate new materials.

Since the logic of art is approachable from a basic understanding of meaning creation from one's peculiar interpretation of the environment with history of art as guide, studies argue that, there are environmentally present materials and approaches for all the categories in art. Although there are suggestions of optional students' material preferences beyond curricula material schedules, preparation of materials for artistic endeavour, storage, techniques and finishes provided reveal syllabi biases. For instance, the sculpture syllabus' preference for wood, clay, stone, plaster and cement is obvious (CRDD 2010, p4). These preferences constraint candidates in their material choices and content building. Checks suggest similar situations in the other genre syllabi.

Erroneously, the impression carried by the syllabi suggests that certain categories of art, like sculpture is a southern Ghana phenomena. But if one considers leather and straw as materials possible in sculpture, northern Ghana begin to populate itself with sculpture media. These are found in Sirigu pottery representations, musical instruments, Gurunsi dance masks, Bawa dance rattles, bows and arrows, grafted leather, indigenous furniture forms, architecture, architectonics and murals. Although they may not appear in similar fashion and scale as they do in the south, they amount to traditions worthy of recognition and by extension, into sculpture. These have ways they impact studies in art, especially at the tertiary level. Architecturally, Northern Ghana presents the most culturally efficient and significant designs. Sadly, our handling of issues deny these designs space within contemporary Ghanaian architecture. The above satisfy only the category of sculpture; there are those for other categories like Sirigu and Bombrosi wall mural paintings, pottery, mat and smock weaving for painting, ceramics and textiles respectively. Candidates from these and other areas in Ghana deserve the opportunity to explore any form of art from their peculiarities without the burden of institutional categories and materials.

Decades ago in Ghana, there were explorations in robotics and automobiles from assorted discarded tins; construction of raffia mummy trucks, Lorries and birdcages, but are almost extinct now. Crafts in erstwhile elementary school curricula; such as plastic sheet birds and seasons' decorations, fabric and fibre door matting etc., constituted cultural endeavour with meanings that incorporate the personal. There are others whose livelihoods depend on vocations, places and circumstances where, for instance trap fishery and bamboo crafts thrive. Others find themselves in urbanised industries with material conditions that blur the lines between social and academic, art and craft. Currently, discarded automobile tyres and plastic utensils are trending in works of Yong Ho Ji, Chakaia Booker and Sayaka Ganz, as they exist uniquely in Ghanaian contexts.

\section{Environment and artistic competences}

The notion of student's environment is the socio-cultural and spatio-temporal complexities of the artist's backgrounds (Jones \& Cloke 2008). These are the conditions that have shaped the senses and endowed them with tools to explore the world (Heidegger 2001, p59). The environment is usually made up of constituent communities and other associations from which individual and collective experiences eventually coalesce into habits and culture. These experiences are ordinarily transcribed into conventional materials like clay and marble, for them to assume some texture and meaning in art, e.g. portrait bust, or pottery.

Environment such as above, in the $21^{\text {st }}$ century popular and visual cultures produce its own materials and objects, and correspondent materiality (Basu 2013; Du Preez 2008; González-Ruibal 2014; Harrison and Schofield 2009; Mills 2009; Miller 2011; Tolentino 2012). Normally, vocations of leading membership like mentors and kin have significant influence in the training of the younger generations through role-playing and active participations. The environment therefore, is a process that continues throughout life (Heidegger 2001). It is shaped by culture, influenced by language, impacted by beliefs, and affected by values. The environment is also moderated by the distinctive features we typically describe as individuality and collectivity, as well as aptitudes relevant in art making and art education (Maddof 2009; Pujol 2009; Eisner 2002).

Competence in its definition has culturally, and synonymously been applied to skill, ability, capacity, capability, efficiency and proficiency. Competence in art is therefore, the aptitudes, efficiencies, and proficiencies in the handling of artistic issues and media. Holistically it is the quality an 
artist must have to function and live as an artist (Delamare \& Winterton 2005; Lanny 2008; Roberts 2011; 2010; Weinert 1999). This, is believed to be the import of CRDD SHS Art curricula (2010), and as good as this intention is for art, the concept of material in this intention overlooks the imports of $21^{\text {st }}$ century practice. The art and practices of today has changed since the mid- $20^{\text {th }}$ century art, and became what it is at the dawn of 21 ${ }^{\text {st }}$ century (Smith 2011). This shift, (Buskirk 2003; Cottington 2005; Smith 2011) among a host of others, signals a cultural change in the material and competence modes in art. With cultural competence overriding simple technical abilities (Andrus 2012, p.23), art institutions "should navigate the orthodoxies that privilege the subject as uniquely creative, a distinct and autonomous realm divorced from other forms of social and cultural production" (Addison \& Burgess 2003, p1).

We shall in the following paragraphs look at WAEC/WASSCE questions from 2011 to 2015 as the other source of the conventional stance on materials, and through historical references and environmental conditions, explain how materials, objects and informal practices in Ghana have been explored elsewhere. Further, we will examine, how our peculiar situations imbue these materials with meanings and energies that validate them artistically.

\section{WAEC/WASSCE questions}

Examinations keep accepted media in the curricula active by the type of responses questions elicit even when the intentions are to inaugurate new materials. Memory created by SHS institutions are usually informed by the curricula instituted to teach a particular subject. WAEC therefore contributes to the state of Ghanaian art, and policies that drive it. The council has over the past two decades and even after the last major reforms (Boasiako \& Asare 2015) shaped institutional memory on art materials. It should also be stated that, WAEC relies on art teachers for the supply and moderation of examinable questions for its examinations.

For the past five years (2011-2015), questions have been consistent in prescribing forms, techniques and materials by implications. The selection of questions for the study was skewed towards finding most recent evidence, especially after 2007 Institutional Reforms (Boasiako \& Asare 2015) and curricula reviews (CRDD 2010) that produced the current syllabi. There is no major difference in questions before, or after the 2010 review that produced the"Teaching Syllabus for Art (Senior High School-1-3)" (MOE/CRDD 2010). The following illustrate our concerns:

\subsection{Instructions to candidates}

Answer one question only

Evidence of study (working drawings, designs, studies on paper, etc) must be marked by the Itinerant Examiner and must be submitted together with your finished piece of work, including appreciation of the finished work. This preamble is applicable to all the years.

\section{2}

Answer One question only

1. Make a composition in high relief on the theme "A Curious on the Readiness to Escape from a Predator".

$\begin{array}{lll}\text { Size } & - & 35 \mathrm{~cm} \times 35 \mathrm{~cm} \\ \text { Medium } & - & \text { Terra Cotta or Wood } \\ \text { Finished Appropriately }\end{array}$

2. Model a Torso of a Teenage Girl in a pair of Shorts and a Sleeveless Blouse

$\begin{array}{llll}\text { Height } & - & 30 \mathrm{~cm} & \text { (Upright/Standing on end) } \\ \text { Medium } & - & \text { Optional } & \end{array}$

Give an Appropriate Finish

\section{3}

Answer one question only

1. In any suitable medium, design and execute a medallion to be awarded to the Best Dancer in the next year's Schools Cultural Festival Competition to be held in the region.
Size
Diameter $30 \mathrm{~cm}$
(Disc)

2. Design and execute a sculpture in-the-round on the theme Breastfeeding.

Medium:

Optional 
Height: $30 \mathrm{~cm}$

(Upright/Standing on end)

\section{4}

Answer one question only

1. Design and execute a medium relief in any suitable material based the theme: REFUGEES

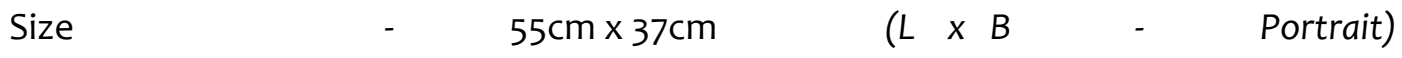

Give an appropriate finish

Portrait)

2. Design and model in-the-round, a sculpture depicting STRENGTH

$\begin{array}{lll}\text { Height } & - & 30 \mathrm{~cm}\end{array}$

\subsection{Resultant material consideration}

Consistently, WAEC has subtly restricted candidates to form and content (materials, techniques and representational formats), compelling instructors and institutions to react and create in specific ways. Taking this phenomenon a couple of decades back, memories accumulated have informed the institutional curricula and the instructional tendencies under discussion. In sculpture, though 3 dimensional, have 2 dimensional measurements in reliefs and in-the-rounds with themes, materials, techniques and formats. Where materials are not specified, (2013/2014) technique given automatically gives one material through the instructional manual (syllabi), and from institutional memories accumulated since the educational reforms in 1987, and even before that. Observations suggest that, when candidates are given options to select their own materials for their work, they unconsciously produce monotonous works with institutionally prescribed media, and that even WAEC seems to have inherited their peculiar tendencies in examining candidates from the Cambridge system that preceded, and bequeathed to it, the right to examine. This confirms the colonial curricula traits (seidou 2014a; 2014b; Woets 2012), despite the almost 10 time educational reforms carried out (Boasiako \& Asare 2015; Tonah 2009).

For sculpture, material requirements are clay, wood, plaster, cement and sometimes papier mache, in relief and in-the-round. Painting and Graphics have pigment and occasionally, picture and fabric mosaics on paper or boards as their correlative materials. In all these, there is hardly collage (modernist modes) as a bridge between 2 and 3 dimensional arts, as requirement within one category e.g. painting. For textiles, cotton, fabric and dyes are all there is. Ceramics has its clay, whiles weaving and basketry have palm, cane and straw, ignoring threads, twines and fibres (natural and synthetic), as in macramé and crocheting. There is no crossover of domains, but as categorised within the syllabi. Within current syllabi categories, it is impossible to explore sculpture with materials and techniques of leather or fabric, weaving and basketry, or painting and graphics with the computer. Textiles are also difficult to explore through weaving of fibres and straw even though they do exist in both the indigenous and current artistic practices.

\subsection{Deskill and reskill: Artistic competence at SHS level}

To vividly illustrate the idea of deskilling and reskilling, a couple of works by renowned artists have been selected to illustrate necessary social aspects of the SHS Students and WASSCE candidates, and to show what they have through the familial and environmental associations for development as materials and techniques in their art (Andrus 2012; Du Preez 2008; Heijnen 2015; Heidegger 2001; Stankiewicz 2009).

A critical look at El Anatsui's Gawu (2003-2008) (figure 1.), or Ibrahim Mahama's Non-Orientable Nkansa (2017) (figure 2.), with their materiality, series of memories and recollections are invoked (Erickson 2005; Freedman 2003). They represent our visits to the drinking bar, and pushing aside the stringed bottle top curtain, or the bangs and calls of shoeshine boy/box, or the charcoal vendor, when for instance, Ibrahim Mahama's entire repertoire is invoked. These memories create varied fertile conditions for the art student (Heijnen 2015). Sayaka Ganz and Yong Ho Ji have artistic practices that border on vulcanizing and plastic scavenging. Locally, numerous products are derived from the used automobile tires and tubes, but Yong Ho Ji explores their mutations into art in his Bull man (figure 3), same as Sayaka Ganz's Horse (figure 4). These works are suspended between recycling and cultural 
regeneration (Krauss 1999 in Du Preez 2008); a form of cultural production and meaning making that could inspire candidates whether one becomes an artist or not. Skills for such productions do not exist in the existing syllabi, but are the mainstay of art now. Skill forms and materials/objects variations abound in Ghana, especially with El Anatsui's bottle top representations, Ibrahim Mahama's work, Mai Thomas's and George Sugarman's fish trap sculptures, and Andy Goldsworthy's serendipitous stone and wood representations, especially for students from similar environments (Heijnen 2015).

It should be reiterated that, artists and works chosen were informed by availability of such materials or objects, aptitudes and distribution of practice, as well as their local associations (Andrus 2012; Roberts 2011; Stankiewicz 2009; Grushka 2009; Du Preez 2008). Locally, a lot of young people have had unconscious, and potentially artistic experiences through vocations in hair crafts (barbering/braiding/hairdressing), weaving, dressmaking; discarded automobile tire shoemaking ("Taawoto"); fishing (fish traps ("Agyookuo") and twines, canoe carving, painting and decoration; farming (scare-crows, hunting traps, birdcages), masonry, plumbing, mechanic and merchandising, etc. Awareness of their respective experiences as beginners even in the traditional medium (Painting/Sculpture/Textiles etc.) would be a big leap in our artistic training and practices (Heijnen 2015).

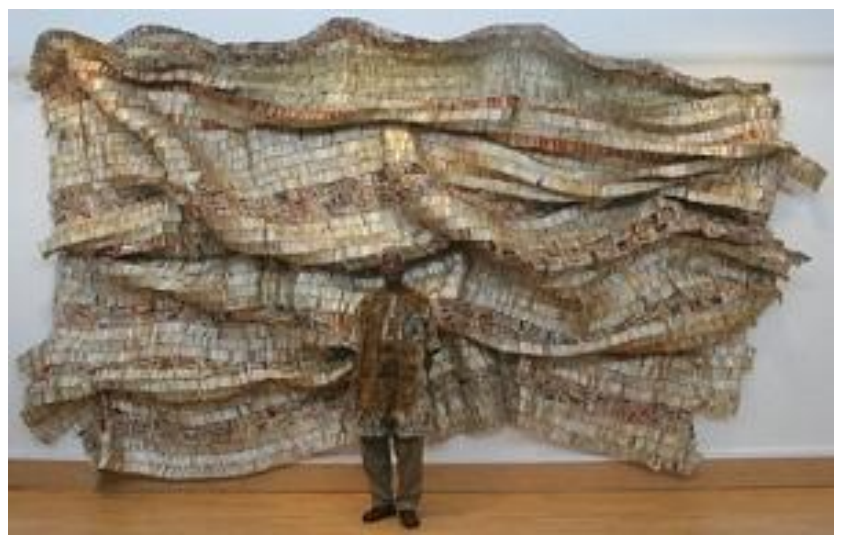

Fig 1: Gawu 2003-2008.

El-Anatsui Reconditioned Bottle-tops.

Courtesy - Fowlers Museum UCLA

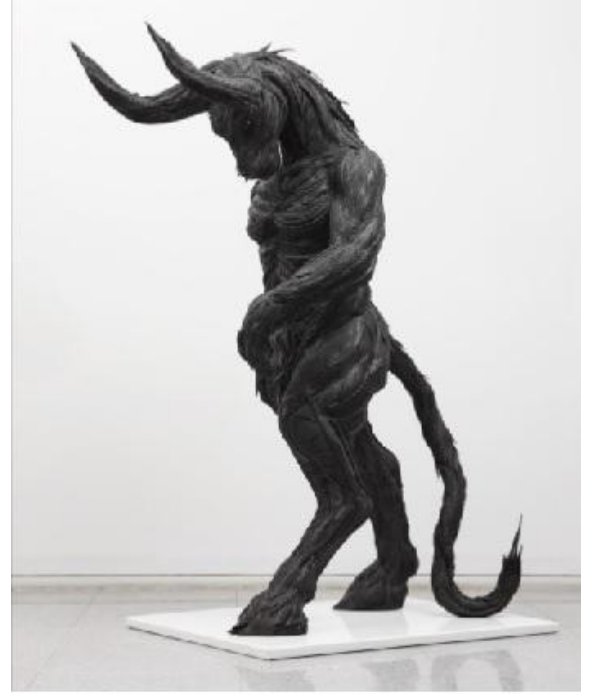

Fig 3. Bull Man 42010 (100X150X200cm).

Yong Ho Ji. Used Tire, Steel, Synthetic Resin

Courtesy - The Source

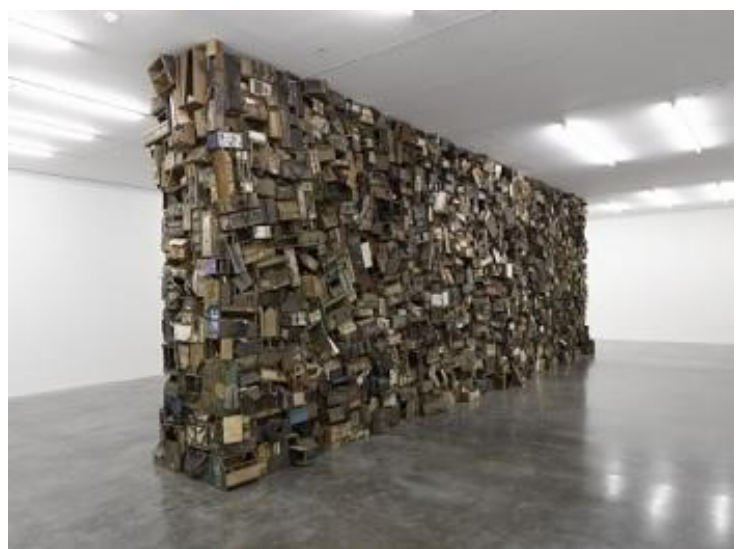

Fig 2: Non-Orientable Nkansa 2017. Ibrahim Mahama. Mixedmedia (Variable). Courtesy - White Cube (George Darrell)

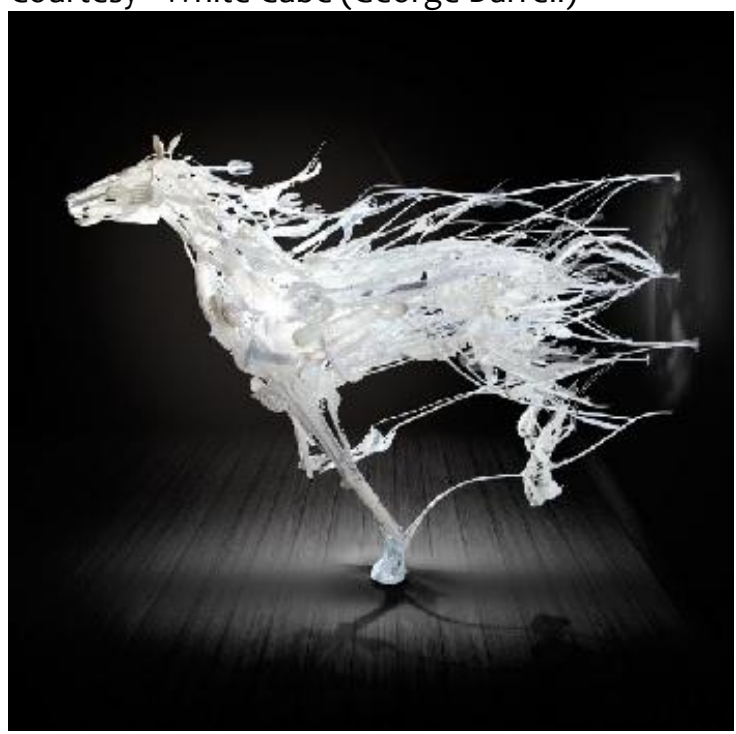

Fig 4. Horses 2013 (Detail).

Sayaka Ganz Used and Discarded Plastic Utensils Courtesy- Sayaka Ganz Reclaimed Creations.

\section{Conclusion}

Art is its materiality (Mills 2009). It is the form, content and context; the form being representational qualities of its materials and formats (Hickman 2012; Mills 2009). Content is issues and 
style carried by the work, while context is theoretical underpinnings. Roberts (2011) puts this succinctly that, "art is ... but also the outcome of a set of shared iterative skills, temporal forms and collective relations" (p.47). Art is an ensemble of functions and discourses within our cultural and meaning production- the continual conceptual coding, organization, distribution, contextualization and interpretations of cultural signs (Du Preez 2008; Heijnen 2015).

This paper has argued that, media and aptitude requirements of the SHS syllabi (MOE/CRDD 2010) is inhibitory and not in tune with current trends in art (Heijnen 2015; seindou 2014a; 2014b; seirdou, et all 2015). We have also argued on how institutional approval of certain materials and skill types over others through WAEC examinations subtly downplays the essential vernacular skill development of the Ghanaian art student (Heijnen 2015, p287-290). Environmentally, these students are prepared with meaningful pure and material cultures they respond to and negotiate through role-playing, participation and practice. These material modes and practices are synonymous with current skill forms in art, as they exist outside the SHS syllabi and could be critical in the training of artists in Ghana (p287). We have, through illustrations in works of El Anatsui, Ibrahim Mahama, Sayaka Ganz and Yong Ho Ji, shown contemporaneous media/objects and competences in Ghanaian familial modes and vernacular practices.

Materials and skill forms suggested in this paper offer themselves in vernacular for those who are aware of their potentialities in artistic explorations. We are not in any way suggesting that all students at the SHS level will come to any of these materials equally, or the conventional materials should be totally discarded (Heijnen 2015, p289). As discussed, these materials become plausible, then conventional depending on one's environment, and should be balanced effectively, and that material selection for art, especially at the examination levels should be personal. The conventional should stay as part of instructional materials, but not portrayed as ultimate among equally credible others, because a simple spoon may mean several things to different people, same as clay, straw, plaster, fabric, pigment and many others. These meanings, achieved through cultural objects in conjunction with artistic traditions and discourses are what authors' anticipate. We suggest a re-orientation of teaching and learning of studio art at the SHS level away from teacher/student centeredness, by approaching artistic projects from candidates' immediacies to our common realities with understandings that blur the borders between personal, social, academic, historic, fantasy and present realities (Grushka 2009; Hansen 2007).

Authors believe that, curricula reviews will invariably open the school system to the environment lying outside it, and see the admission of "new" materials that would create specific objects and forms outside institutional categories and expectations (Heijnen 2015), to usher in significant cultural productions, from architecture to industrial design, into artistic view. It will also change modes of instructions and assessments, and above all give room for the crafting of curricula that will produce competent cultural practitioners. Institutional considerations which incorporates among others candidates' bio-psychosocial dispositions should also be encouraged to ensure increased media democratisation for various personalities, alternative sites of learning and relevant methodologies (Wexler 2012; Grushka 2009; Du Preez 2009; 2008). By democracy, we do not mean to suggest wholesale media admission in art at the SHS level (Erickson 2005; Freedman 2003; Gude 2004), but based on demonstration of "critical and creative thinking, technical, behavioural and social skills" (Heijnen 2015, p288)

So far, the syllabus for art at the SHS level is congested and overloaded with subjects not fitting allotted spaces. Curriculum designers should figure out the best approach to art in our secondary schools by evacuating some courses to create space in the curricula, to accommodate new practices and materials, scrap book and journal keeping whiles maintaining some aspects of the convention with art history. It should be emphasized that, "Children from diverse social, cultural, familial and economic backgrounds possess different "funds of knowledge"... which they bring to school and that teachers need to know about and employ them in their teaching" (Andrus 2012, p34). The emphasis at the SHS should be on art, historical antecedents, drawing and design and how "available materials" fit into these discourses. These have implications on policy formulation on future curricula preparations. Policies on inclusive curricula that are sympathetic to students' multiplicity of bodily and mental states is urgent. So is co-opting leading art practitioners in curricula formulation, and also on continuous education for the SHS teacher to keep up with emergent practices in art to be rigorously pursued. 


\section{References}

Addison, N. \& Burgess, L. (2003). Introduction: Core Debates and Issues. Issues in Art and Design Teaching. Nicholas Addison and Lesley Burgess (Eds), London and New York: RoutledgeFalmer.

Anatsui, E. (2003-2008). El Anatsui: Gawu. April 22, 2007 to August 26, 2007. Fowlers Museum UCLA (An Oriel Mostyn Gallery Touring Exhibition) http://www.fowler.ucla.edu/exhibitions/el-anatsuigawu

Andrus, L. (2012). Teaching Urban Students with Special Learning Needs: What We Have Learned through the Art Partners Program. The Intersection of Arts Education and Special Education: Exemplary Programs and Approaches. Sharon M. Malley, (Ed.).The International Organization on Arts and Disability. The John F. Kennedy Center for the Performing Arts.

Annku, M. F. \& Lodonu, J. (2012). Consumption of Visual Art Forms in Contemporary Ghana. International Journal of Humanities and Social Science (2) 17, 245-250. http://www.ijhssnet.com/journals/Vol_2_No_17_September_2012/26.pdf

Artwatch Ghana (2017). The state of Creative Arts in Ghana. 2017 Artwatch Ghana Annual Report (Research Report 15042017). Ghana: Artwatch Ghana. https://www.newsghana.com.gh/wpcontent/uploads/2017/04/THE-STATE-OF-CREATIVE-ARTS-IN-GHANA-final.pdf

Basu, P. (2013). Material Culture: Ancestries and Trajectories in Material Culture Studies. Handbook of Sociocultural Anthropology. James G. Carrier, Deborah B. Gewertz (Eds) Berg, Oxford.

Boasiako, A. \& Asare, B. E. (2015). The Multiple Streams Framework and the 1996 and 2007 Educational Reforms in Ghana. Advances in Research 5, 3, 1-15.

Buchli, V. \& Lucas, G. (2001). The absent present: archaeologies of the contemporary past. Archaeologies of the contemporary past. Victor Buchli and Gavin Lucas (Eds.), 3-18. Routledge London.

Buskirk, M. (2003). The contingent object of contemporary art / MIT Press, Cambridge, Massachusetts. Carroll, N. (2002). Philosophy of Art: A Contemporary Introduction. Routledge, London.

Cottington, D. (2005). Modern Art: A Very Short Introduction. Oxford University Press Inc., New York.

CRDD (2010). Teaching Syllabus for Sculpture (Senior High School -1-3) Ministry Of Education / Curriculum Research and Development Division (Ghana Education Service).

Delamare, F. L. D. \& Winterton, J. (2005). What Is Competence? Human Resource Development International, Vol. 8, 1, 27 - 46, March 2005 http://org822orenner.alliant.wikispaces.net/file/view/

Derrida, J. [1997 (1967)]: Of Grammatology. Gayatri Chakravorty Spivak (Trans). John Hopkins University Press, Baltimore

Du Preez, A. (2009). Introduction. Taking a Hard Look: Gender and Visual Culture. Amanda du Preez (Ed.). Cambridge Scholars Publishing, Newcastle.

Du Preez, A. (2008). (Im) materiality: On The Matter of Art. Image and Text: A Journal for Design 14, 3041

Edusei, K. (2004). An Overview of Visual Art Education in Ghanaian Schools. Journal of Science and Technology, (24) 2, 116-120 http://ir.knust.edu.gh/bitstream/123456789/5105/1/K.Edusei.pdf

Efland, A. D. (2007). Arts Education, the Aesthetic and Cultural Studies. International Handbook of Research in Arts Education. Liora Bresler (Ed), Dordrecht: Springerhttps://www.researchgate.net/profile/Kathleen_Gallagher/publication/226553037_Concep tions_of_Creativity_in_Drama_Education/links/oob7d51bgfd259a502000000/Conceptions-ofCreativity-in-Drama-Education.pdf

Eisner, E. W. (2002). The Arts and the Creation of Mind. Yale University Press/New Haven \& London.

Erickson, H. L. (2005). Concept-Based Curriculum and Instruction: Teaching Beyond the Facts. ELI Explorations 1, http://net.educause.edu/ir/library/pdf/eli4001.pdf

Essel, O. Q., Agyarkoh, E., Sumaila, M. S. \& Yankson, P. D. 2014). TVET stigmatization in developing countries: reality or fallacy? European Journal of Training and Development Studies, 1(1), 27 - 42.

Flolu, E. J. (1997). Music in Ghanaian Education. The African Educator, 9, Dec 1997.

Freedman, K. (2003).Teaching Visual Culture: Curriculum, Aesthetics, and the Social Life of Art. Teachers College Press, Columbia University, New York, NY

Ganz, S. (2013). Horses. Emergence at the Bumbershoot, Seattle, WA, August $31 \sim$ September 2, 2013 http://sayakaganz.com/2013/08/bumbershoot/ 
González-Ruibal, A. (2014). Archaeology of the Contemporary Past. Encyclopedia of Global Archaeology. Claire Smith (Ed.), 1683-1694. New York: Springer. http://digital.csic.es/bitstream/ 10261/109507/1/Archaeology

GoG (2004). Cultural Policy of Ghana. National Commission on Culture, Ghana.

Grosz, E. (2008). Chaos, Territory, Art: Deleuze and the Framing of the Earth. New York: Columbia University Press.

Grushka, K. (2009). Exploring Visual Culture and Gender through Discursive Performative Visual Art Practices. Taking a Hard Look: Gender and Visual Culture. Amanda du Preez (Ed.). Cambridge Scholars Publishing, Newcastle.

Gude, O. (2007). Considerations for a 21st-Century Art \& Culture Curriculum Author(s): Art Education, 6o, 1, 6-17 http://www.jstor.org/stable/pdf/27696187.pdf?refreqid=excelsior\%3A8aced45a87aof182 82008 cda8196efob

Gude, O. (2004) Postmodern Principles: In Search of a 21st Century Art Education. Art Education, 57, 1, pp6-14 http://www.tandfonline.com/doi/pdf/10.1080/00043125.2004.11653528

Hansen, C. (2007). "Understanding Materiality and Human Experience through Creative Artistic Exploration", Journal of Iberian Archaeology, 9, 10, 55-69. http://repository.wit.ie/290/1/MatCult_ CHansen_07.pdf

Harrison, R. and Schofield, J. (2009). Archaeo-ethnography, auto-archaeology: Introducing archaeologies of the contemporary past. Archaeologies, 5, 2, 185-209. http://oro.open.ac.uk/ 18343/2/Archaeologies_Introduction_FINAL.pdf

Harvard Competency Dictionary (n.d.). Harvard University. https://www.campusservices.harvard.edu /system/files/documents/1865/harvard_competency_dictionary_complete.pdf.Retrieved 03/01/2016

Heidegger, M. (2001). Being and Time. John Macquarrie and Edward Robinson (Trans.). Blackwell, Oxford.

Heijnen, E. (2015). Remixing the Art Curriculum: How Contemporary Visual Practices Inspire Authentic Art Education. Amsterdam: The Text Company/Platform P. http://www.emielheijnen.net/files /RTAC\%20EMIELHEIJNEN.pdf

Hickman, R. (2012). Why We Make Art. Visual Arts: Why Art Matters. Sarah Cunningham (Ed.), 13-14. Intellect, Bristol.

Ji, Y. H. (2010). Bull Man. http://www.designboom.com/art/yong-ho-ji-hybrid-human-tire-sculptures http://thesource.com/2014/01/15/sculptures-made-from-tires-by-yong-ho-ji/

Jones O. \& Cloke P. (2008). "Orchard" from Tree Cultures: The Place of Trees and Trees in their Place. The Cultural Geography Reader. Timothy S. Oakes and Patricia L. Price (Eds). Routledge, New York

Lanny, V. (2008). Differentiating Competence, Capability and Capacity. Innovating Perspectives Volume 16, 3. http://innovationsthatwork.com/images/pdf/Juneo8newsltr.pdf

Madoff S. H. (2009). Introduction. Art School: Propositions for the 21st Century. Steven Henry Madoff (Ed.), ix-xi. MIT Press, Cambridge, Massachusetts.

Mahama, I. (2017). Non-Orientable Nkansa. Fragments. 1 March - 13 April 2017, Bermondsey, North Galleries, Inside the White Cube 2017whitecube.com/exhibitions/ibrahim_mahama_inside_the_ white_cube_2017/

Masoga, M. (2005). Establishing dialogue: thoughts on music education in Africa. Emerging Solutions for Musical Arts Education in Africa. Edited by Anri Herbst. Cape Town: African Minds. Selected articles prepared in advance for the 2003 PASMAE conference and commissioned research-based chapters on the collective voice of conference participants Kisumu, Kenya, 5 to 11 July 2003 http://www.africanminds.co.za/wp-content/uploads/2012/05/Emerging\%20Solutions\%20for\%20Mus ical\%20Arts\%20Education\%20in\%20Africa.pdf

McDowell, L. \& Court G. (2008). "Performing Work: Bodily Representations in Merchant Banks" The Cultural Geography Reader. Timothy S. Oakes and Patricia L. Price (Eds). Routledge, New York: NY

MoE (2010). Education Sector Performance Report. Ministry of Education, Ghana. http://www.idpfoundation.org/Ghana\%20MoE\%20Ed\%20Performance\%20Report\%202010.pdf

Miller, D. (2001).Why Some Things Matter. Material cultures: Why some things matter. Daniel Miller (Ed.), 3-21. UCL Press Limited, Taylor \& Francis Group, London

Miller, D. (2011): Getting Things Right: Motherhood and Material Culture Studies in the Maternal, 3, 2, 2011, www.mamsie.bbk.ac.uk 
Mills, C. M. (2009). Materiality as the Basis for aesthetic Experience in Contemporary Art. Thesis, Dissertations, Professional Papers, 1289. http://scholarworks.umt.edu/etd/1289

Mirzoeff, N. (2006). On Visuality. Journal of visual culture. Vol 5, 1, 53-7. http://nicholasmirzoeff.com/ Images/Mirzeoff_visuality.pdf

Mirzoeff N. (2011). The Right to Look. Critical Inquiry. Vol 37, 3, 473-496 http://nicholasmirzoeff.com /RTL/wp-content/uploads/2011/06/RTL-from-Cl.pdf

Mirzoeff, N. (1998). What is Visual Culture? The Visual Culture Reader. Nicholas Mirzoeff (Ed.), with introductions, 3-13. Routledge, London.

Mitchell D. (2008). "California: The Beautiful and the Damned" from the Lie of the Land: Migrant Workers and the California Landscape. The Cultural Geography Reader. Timothy S. Oakes and Patricia L. Price (Eds). Routledge, New York

Najam A., Runnalls, D. \& Halle, M. (2007). Environment and Globalization: Five Propositions. International Institute for Sustainable Development, Winnipeg, Manitoba, Canada. https://www.iisd.org/pdf/2007/trade_environment_globalization.pdf

National Art Education Association (2010). Learning in the visual age: the Critical Importance of VISUAL ARTS EDUCATION. National Art Education Association. http://www.arteducators.org/learning/ learning-in-a-visual-age/3_NAEA_LVA_10.pdf

Olsen, B. (2003). Material Culture after Text: Re-Membering Things. Norwegian Archaeological Review, Vol. 36, 2, 87-104. http://www.staff.amu.edu.pl/ ewa/Olsen

Opoku-Asare, Nana Afia \& Siaw, A. O. (2016). Curricula and Inferential Factors That Affect Student Achievement in Rural, Urban, and Peri-Urban Senior High Schools in Ghana: Evidence from the Visual Arts Program. Sage Open $1-13$ http://journals.sagepub.com/doi/pdf/10.1177/2158244016661 747

Opoku-Asare, N. A., Tachie-Menson, A. \& Essel, H. B. (2015). Perceptions, Attitudes and Institutional Factors that Influence Academic Performance of Visual Arts Students in Ghana's Senior High School Core Curriculum Subjects. Journal of Education and Practice (6) 21, 39-49. https://files.eric.ed.gov/fulltext/EJ1079077.pdf

Opoku-Asare, N. A., Tachie-Menson, A \& Ampeh, G. K. (2015). Instructional strategies for effective teaching and learning of creative arts: the dilemma of generalist teachers in Ghana. Global Journal of Human-Social Science: A Arts \& Humanities - Psychology, 15(5), 7 - 15.

Pretty J., Ball A., Benton T., Guivant J., Lee D. R., Orr D., Pfeffer M. and Ward H. (2007). Introduction to Environment and Society. http://www.corwin.com/upm-data/17276_01_Pretty_Cho1.pdf

Pujol E. (2009). On the Ground: Practical Observations for Regenerating Art Education. Art School: Propositions for the 21st Century. Steven Henry Madoff (Ed.), 1-13. MIT Press, Cambridge, Massachusetts.

Roberts, J. (2011). The Intangibilities of Form. Variant 41, 43-47. http://www.variant.org.uk/pdfs/issue 41/jroberts41.pdf

Roberts J. (2010). Art after Deskilling. Historical Materialism 18, 77-96. http://platypus1917.org/wpcontent/uploads/2010/09/robertsjohn_artafterdeskilling2010.pdf

Rose, Gillian (2002). Visual Methodologies: An Introduction to the Interpretation of Visual Materials. Sage Publication Ltd, London.

sei'dou, K., Ampratwum, G., Kissiedu, K. B., Riskin R. (2015). Silent Raptures: Emergent Art of the Kumasi College of Art. International Journal of Humanities and Social Science. 5(10), 131-137

seid'ou, k. (2014a). Gold Coast Hand and Eye Work: A Genealogical History. Global Advanced Research Journal of History, Political Science and International Relations ISSN: 2315-506X Vol. 3, 1, 008-016, January, 2014

seid'ou, k. (2014b). Adaptive Art Education in Achimota College: G. A. Stevens, H. V. Meyerowitz and Colonia False Dichotomies. Cass Journal of Art and Humanities January-March 2014, 3, 1, 1-28

Smith, T. (2011). Contemporary Art: World Currents. Laurence King Publishing, London.

Stankiewicz M. A. (2009). Constructing an International History of Art Education: Periods, Patterns, and Principles. The International Journal of Arts Education 7, 1 http://ed.arte.gov.tw/uploadfile/ periodical/2264_00010020.pdf

Tolentino D. J. (2012) Authentic/Adulterated Artifacts: Material Culture and Ethnicity in Contemporary Java and Ifugao. Wacana Seni Journal of Arts Discourse. Jil.,11. http://wacanaseni.usm.my/WACANA 
Tonah, S. (2009). The Unending Cycle of Education Reforms in Ghana. Journal of Education Research in Africa 1, 1, 45-52

Woets, R. (2012). “In Art, Anything Can be A Hit”: The Work and Teaching of kąrîkạchä seid'ou. Time, Trade \& Travel. SMBA Project 1975. SMBA Newsletter, 129. http://www.smba.nl/static/en /exhibitions/time-trade-travel/smba-newsletter-129.pdf

Weinert, F. E. (1999). Definition and Selection of Competencies: Concepts of Competence. SFSO NCES OECD. http://citeseerx.ist.psu.edu/viewdoc/

Wexler, A. (2012). Art, Developmental Disability and Self-Representation. The Intersection of Arts Education and Special Education: Exemplary Programs and Approaches. Sharon M. Malley, (Ed).The International Organization on Arts and Disability. The John F. Kennedy Center for the Performing Arts. 